\title{
ISAD Ad Hoc Committee Reports
}

\section{INTRODUCTION}

After seven years of operation as a division, it is an appropriate time to take stock of the division objectives and to describe desirable future activities of the division. To this end we established in July 1972, four ad hoc committees whose charges were to provide overviews of the division from slightly different perspectives. The first of these, the Committee on Objectives, was to review the activities of ISAD since its founding and to recommend future objectives and general activities. Second, the Seminar and Institute Topics Committee was charged with reviewing past ISADsponsored institute activities and with recommending topics for future seminars and institutes which would be of most value both for the ISAD membership and for general library personnel. The third committee, Research Topics, was charged with assembling a priority list of ISAD-related research and development needs of libraries. And, the fourth committee, Membership Survey, was charged with determining by a survey important characteristics of the current ISAD membership, i.e., their employment, experience, education, interests, and expectations.

It can be seen from their charges that there is an interrelationship among the committees and thus, in the work to meet their charges, the committees would certainly wish to know the results of the work of the other committees. However, because of problems of timing and communication, it was recognized that the initial committee work would have to be carried out largely independent of the work of the other committees and that the task of knitting these committee results together would have to be carried out after the committees finished this stage of the work.

The report of the Committee on Objectives was reviewed and accepted by the ISAD Board of Directors at the national meeting in Las Vegas. The work of the Seminar Topics Committee and the Research Topics Committee has not been reviewed by the Board of Directors. They are presented here in order to elicit thought and comment by the ISAD membership. The Membership Survey Committee has established the survey to be carried out, but the survey has been delayed until funding could be obtained. This funding has been made available and analysis of survey results will be provided to the membership in the coming year.

I should like to thank not only members of the ad hoc committees for their contributions to the division during the past year, but also, the members of the standing committees, the representatives and the chairmen of the discussion groups, all of whom contributed to an active, interesting and useful year for the division.-Ralph M. Shoffner, Past-President, Information Science and Automation Division. 


\section{Report of the Committee on Objectives}

\section{BACKGROUND}

On January 27, 1966, the Council of the American Library Association voted to establish ALA's fourteenth division, the Information Science and Automation Division, which would concern itself, said the Council, "with the development and application of electronic data processing techniques and the use of automated systems in all areas of library work." Before this date, there was no membership unit within ALA with the sole responsibility for library automation, so there was no effective way for librarians involved with automation to communicate, or to learn from each other's experiences. There was also no way for the national professional association to provide leadership for those in need of information and guidance in the field, since responsibility for the area (to the extent it had been recognized at all) lay fragmented among various units within ALA. Two of the most important objectives of the division at the beginning, therefore, were the establishment of professional leadership at a national level (largely through the office of the executive secretary) to those libraries and librarians needing advice and help in the field of library automation, particularly smaller libraries unable to afford competent staff members with assigned responsibility in this area; and provision of a forum for discussion of library automation problems and experiences, and other means of communicating information in the field.

A number of specific activities were also suggested at the beginning, including the following:

1. the establishment of a journal which would pull together articles on library automation, which at that time were appearing in many different places;

2. provision of a clearinghouse for information on library automation projects;

3. creation of a "bank" of computer programs and related documentation for use by other libraries planning similar applications;

4. evaluation of library automation equipment and applications;

5. tutorial seminars, preconference meetings and other educational programs.

Other concerns or matters suggested to the ALA Committee on Organization for immediate attention by the new division included:

1. standardization of coding systems;

2. interlibrary distribution of bibliographic data in machine-readable form;

3. shared programming;

4. establishment of library communication networks;

5. automated searching techniques;

6. compatibility of equipment and programming;

7. use measurement and user studies involving automated systems;

8. the financing of cooperative automation projects; and

9. various social and legal problems relating to automation in libraries.

During the first few years of the division's existence, most of these activities were pursued, some of them extensively (the seminars, for example) and others 
for only a brief period of time, until the need no longer seemed to exist. Early committees also considered the need for a special library programming language, the computer aspects of the new copyright bill (then being drafted), and the method of designating periodical publications known as CODEN.

\section{THE COMMITTEE ON OBJECTIVES}

In the spring of 1972, Ralph Shoffner, the incoming president of ISAD, appointed an ad hoc Committee on Objectives to consider and present formal recommendations regarding the future objectives and activities of ISAD. Part of the thought behind appointment of the committee was that since ISAD had been in existence for five years it would be an appropriate time to review both its activities and objectives, and even to consider whether the division should continue to exist; it also seemed likely that some of the original objectives of the division might have been attained, or might no longer be appropriate, and a revised set of objectives might be needed for the forthcoming years.

Besides this writer, the committee has included Frederick G. Kilgour of the Ohio College Library Center; Henriette Avram of the Library of Congress; John McGowan of Northwestern University; John Knapp of Richard Abel \& Company; Joseph Treyz of the University of Wisconsin; and Pauline Atherton of the School of Library Science at Syracuse University. The membership of the committee was intended not only to incorporate knowledge of ISAD's history and informed judgment of the need for various possible activities in the future, but also to be as representative as possible of the various types of library activity and the types of institutions presumably served by the division.

\section{FIRST MEETING AND TENTATIVE CONCLUSIONS}

The committee held its first meeting on Wednesday, June 28, 1972 during the ALA Annual Conference in Chicago. After considerable discussion, it was clear that the consensus of the committee members, based on their own experiences and the comments of colleagues to whom they had talked, was that:

1. the education function has been important, and should be continued, especially the seminars, which have been very useful (at least 2,000 people have attended the MARC Institutes co-sponsored by ISAD and the Library of Congress, and hundreds more have attended seminars on other topics at local, regional and national meetings);

2. the Journal of Library Automation and Technical Communications have also been useful, and should not only be continued but improved and expanded;

3. the executive secretary provides a focus for inquiries from libraries needing help and advice, and has provided much useful information to many libraries and librarians;

4. the idea of a computer program "bank" is not practical at this time, largely because of the costs to ALA in terms of staff and operating expenses that such a project would entail;

5. evaluation of equipment and applications is still needed, but would require more staff and expertise than the association can fund at this time;

6. the division has provided useful forums for discussion, particularly such forums as the MARC Users Group which meets twice a year to exchange ideas and ask questions of staff members from the MARC Office at LC; 
7. the division has also served a useful function in the promotion and development of standards, and in determining whether the standards have broad support in the library profession;

8. the division has helped to coordinate the concerns of other parts of ALA regarding automation and information science, both through the executive secretary's office and through such devices as the preconference institute on data bases.

The general but tentative conclusion was that the division should continue, but with a revised set of objectives, emphasizing the educative function, the provision of current information through various means, and the development and promotion of standards.

\section{REQUESTS FOR COMMENT AND RESPONSES}

The committee then decided to test these tentative conclusions by asking the opinions of a number of librarians and others who appeared to be in a position to judge the effectiveness of ISAD (or the lack of it), or who could be expected to reflect a useful variety of viewpoints. Each was sent a letter outlining the purposes of the committee and the tentative conclusions, followed by a request for written comments; each was also invited to attend the next meeting of the committee in January 1973 at the Midwinter Meeting in Washington.

The responses by and large agreed with the tentative conclusions, but in many cases went further. For example, it was suggested that the division should take a more active stance, and should emphasize such things as making services available (especially through cooperation) that could not be made available before, reducing library operating costs, making the work of library staff more meaningful, minimizing the impact of library automation on people and jobs, encouraging research in library automation, and encouraging instruction in library automation for all students in library schools. It was also suggested that more emphasis be placed on reporting new developments at the annual meetings, after the model of the American Society of Physics, and that the division should be a vehicle for a "new librarianship" in which librarians would participate more fully in education and research rather than acting solely as a "service" organization.

Another respondent commented that more active liaison was needed with other professional groups in the information processing field, e.g., ASIS, AFIPS, JCET, etc.; that transferability of programs and applications should continue to be encouraged; and that library schools should be encouraged to offer more courses in library automation.

Many of those who received requests for comment accepted the committee's invitation to attend the Midwinter Meeting in Washington, and added other points of view. Among them were suggestions that ISAD should do more toward developing the utilization of machine-readable data bases, including the production of indexes to such data bases; foster and encourage computer-based library networks; and promote methods of accountability for librarians and libraries through development of techniques for measuring unit output of products and services.

\section{INFORMATION TECHNOLOGY}

One new and large area of activity for ISAD was also formally suggested at this meeting: leadership in, and organizational responsibility for, audiovisual 
and related educational technologies, including cable television. The origins of this suggestion date back some months before the Washington meeting, and since adoption of this suggestion would entail a major enlargement of ISAD's area of responsibility it may be useful to provide the background.

At present, ALA has an Audiovisual Committee established during the reorganization of the late fifties, plus five divisional subcommittees officially tied to the Audiovisual Committee, and approximately nineteen other committees actively concerned with audiovisual matters but with no official connection to the ALA Audiovisual Committee. This structure has not provided a "home" for media specialists or a focus for their interests and activities, and ALA has been criticized for years for its sporadic and disjointed attempts to give proper attention to audiovisual matters.

In 1971, Don S. Culbertson, then executive secretary of ISAD, expressed formal concern over this issue to the ISAD board and proposed the establishment of an Educational Technology Section within ISAD. Following this, ISAD and the ALA Audiovisual Committee agreed to a discussion group within ISAD to determine the extent of interest and need for such a membership "home."

The ISAD Information Technology Discussion Group, formed as a result of this initiative, met first on June 28,1972 , at the Chicago conference. Those present discussed areas of need and alternative organizational approaches, including the present organization of committees and subcommittees; the present organization, but with all committees reporting to the ALA Audiovisual Committee; a Round Table; and affiliation with ISAD. Becoming a part of ISAD seemed to this group to offer the most advantages: ISAD was an established division, capable of accommodating diverse interests, and with many concerns in common with the media specialists; it was already active in many areas of interest to media specialists, particularly standards development and educational programs; and affiliation would offer access to the two divisional publications, JOLA and JOLA Technical Communications.

Louise Giles, leader of the Discussion Group, and Pearce Grove, chairman of the ALA Audiovisual Committee, then met with the ISAD board and requested formal affiliation. The board referred the group to the Committee on Objectives, and on January 30, 1973, Mrs. Giles, Mr. Grove, and others interested in this request attended the Midwinter Meeting of the committee. Discussion of this group's petition merged with the discussion of other activities of the division, as reported above, but the committee was unanimous in feeling that the group's request should be granted, and that the activities of ISAD should include audiovisual and related educational technology.

\section{RECOMMENDATIONS}

As a result of its deliberations, and based on the comments and testimony of many interested and affected ALA members, the committee now recommends the following:

1. that the division continue to exist;

2. that its area of responsibility include audiovisual and related educational technology;

3. that the objectives of the division be:

a. advancement of the state of the art of librarianship via research in, and application of, information science and library automation; 
b. professional leadership at the national level in the fields of information science and library automation;

c. education and communication of information in these fields for libraries, librarians, and other interested parties;

d. provision of expertise and assistance in these fields to other units of ALA, and to other professional organizations;

4. that among other activities the division pursue, or continue to pursue, the following:

a. publication of the Journal of Library Automation, Technical Communications, and other publications that may from time to time appear necessary, appropriate, and feasible;

b. provision of forums for communication of information in its fields of responsibility, including local, regional, and national seminars, institutes, regularly scheduled meetings, discussion groups, and special programs on specific topics;

c. promotion of the development and use of appropriate standards;

d. investigation, largely through committees, of matters of immediate, even though temporary, concern to the profession, within the division's area of responsibility;

e. encouragement through various means of techniques, approaches, and specific activities outside the division which are desirable for the profession (such as computer-based library networks, increased instruction in library automation and information technology in library schools, costeffectiveness in automated library systems, and development of the utilization of machine-readable data bases);

f. liaison with other professional organizations in its fields of responsibility.

Respectfully submitted, Pauline Atherton Henriette Avram Frederick G. Kilgour John Knapp John McGowan Joseph H. Treyz Stephen R. Salmon, Chairman 


\section{Report of the Committee on Research Topics}

\section{INTRODUCTION}

We take it as axiomatic that the fundamental purpose of library automation is to increase the productivity of people who work in libraries. A necessary concomitant of this is that we must know what it is that people who work in libraries do. The question of what they should do is a deeper question, but not one that experts in automation are likely to shed much light on. What is new in the elicitation of the contents of library work is the need for specification at a level of detail not needed when one must only specify for human direction.

At the first, most elementary, level much of this has now been done. At least 25 or 30 major academic and public libraries have well-tested, working systems in operation and perhaps as many as 100 more have significant operations underway. The fact that some operations have failed outright, or fallen far short of promise, or been far too expensive, does not detract from the fundamental fact that a number of promising, economic systems are now in place and can be replicated throughout the library world at will. In this category we would place book catalog systems, basic circulation and acquisitions systems, and, more recently, card catalog production systems. Such performance would not have been possible without great attention to detail and without the accumulation of a more precise understanding of how librarians work on these tasks.

The question at hand is, given the developments of the past five years, where do we go from here? At least a portion of the answer lies in the observation that one of the by-products of the initial phase of automation is the creation of substantial data bases in machine-readable form which can be used to provide greater insight into the next higher level of library work. Analysis of this unprecedented mass of data on library activity must therefore be placed high on any priority list of future activity. We shall consider some of the possibilities in traditional terms by enumerating some of the problems in three broad areas of library work: acquisitions, cataloging, and circulation.

\section{ACQUISITIONS}

The fundamental problem in acquisitions is the problem of selectivity. Some rough estimates may help put things in perspective: although we know of no formal estimates of the total number of monographs residing in archives in, say, the English speaking world, it must surely be in excess of twenty million volumes. We do know from the U.S. Office of Education that the median-sized university library has something in the order of 750,000 volumes; thus with the possible exception of the Library of Congress, the British Museum, and (literally) a handful of major university and public libraries there is little hope of ever obtaining a "complete" collection. The problem is not new and librarians have grappled with it for decades-if not centuries-with varying degrees of success.

The several faces of the problem can perhaps best be seen by examining the questions posed by the several members of this committee:

1. How can libraries, with a minimum expenditure of time and money, deter- 
mine how well they are serving their intended audiences?

2. What methodologies exist, or can be created, for dividing collection responsibility among members of a library consortium?

3. Is it possible to develop criteria which libraries of varying size can use to identify not just the subject matter of materials to be purchased, but actually place priorities on serial titles, perhaps some monographs, government documents, etc. which should reside in a given library?

If we presuppose the existence of automated circulation, acquisition, and cataloging systems-with accompanying statistical packages to simplify the routine processing of machine-readable data-the following sorts of studies might help to illuminate these questions:

1. Detailed statistics about who is borrowing what kinds of books; how these borrowing patterns change within a year and from year to year provide useful information about one aspect of library service. Acquisitions data on the number and types of books ordered or suggested by patrons and the turn around time necessary to obtain such items and comparative studies of books obtained at patron request versus books obtained by other means may be helpful.

2. If two or more libraries are to act together in planning their acquisitions, it seems reasonable to suggest that each library should first carefully describe its collection and borrowing pattern at a rather detailed level. Even libraries not formally allied in a consortium would do well to publish more information about their holdings to allow individual users to better judge which of the several libraries available to the user is most likely to contain the desired information.

3. Better circulation data cannot help but be useful in selecting those categories of publications that are likely to circulate well. Periodic examination of citation indexes can shed insight into the problem of selecting periodicals. Individual monograph selection might be improved by accumulating circulation data across a number of similar libraries to provide a "best-circulator" list to go along with the "best-seller" lists already available.

Many such studies have been made in the past. The joint availability of computers and machine-readable records of transactions makes it rather inevitable that their number will increase-with or without the benefit of further research. Given this, it seems reasonable to suggest that in addition to a frontal attack on the problem of selectivity in acquisitions, there should be a substantive effort towards improving the statistical methodology involved in analyzing the available data as well as an attempt to make more readily available those statistical techniques that have already been shown to have application in this area.

\section{CATALOGING}

If the key word in acquisitions is "selectivity," the corresponding term in cataloging is "access." Some of the earliest automation efforts in libraries were directed to the production of machine-readable catalogs and associated programs to produce from such data bases printed book catalogs. Because of the large cost in converting the retrospective catalog, such efforts were largely limited to small collections and had, perhaps, their best application in public library systems where multiple copies of the book catalog had obvious application. In such applications, access was enhanced by the reduced cost of multiple copies which en- 
abled the system not only to maintain complete catalogs at each location but also to make copies available to neighboring institutions such as local school districts.

More recently, the coming into being of the MARC data base has led to the creation of regional and national services for the more rapid creation of catalog card images. In these applications, the primary improvement in access is that provided by time gains that make it possible to get items on the shelf faster, However, some of these services, e.g. OCLC, provide useful by-products such as the creation of an on-line union catalog of the various libraries using the system, thus facilitating interlibrary loan services. Similarly, some automated circulation systems provide increased access to holdings through the use of on-line and/or telephone access to author and/or title catalogs. (Ohio State University, with one of the more sophisticated systems, notes that in each of the first two years of operation, circulation increased 15 percent-considerably more than the growth of the campus community.)

Computers have also been used to multiply the number of available orderings of a shelflist, increase access to titles by permuted title lists, develop use of citations through citation indexes, and increase subject access through accumulation of book indexes in consolidated volumes; in many cases access is further increased by publication-and multiplication of the access through multiple copies. Extensions and refinements will almost certainly continue through the coming decade.

What research, then, is necessary? The following topics seem worthy of consideration:

1. Develop measures of cost effectiveness of various access systems particularly with regard to the relative merits of on-line, telephone, and printed copies of access systems.

2. Systematically enumerate the various types of information requests placed on libraries to obtain a better understanding of what libraries can do to supply needed information as well as documents and bibliographic references.

\section{CIRCULATION}

Some of the most successful automation efforts have been obtained in circulation control, together with some of the most useful by-products. As costs come down, it seems natural to hope that similar usage information might be made available in the noncirculating areas. Specifically:

1. Determine the feasibility of entering records of replacement of documents that were removed from the shelf, but not borrowed, into the existing circulation system.

2. Develop economic means for entering information about "information requests" into the same system.

\section{GENERAL}

In addition to those requests that have been more, or less, accumulated under the traditional headings, we would like to present the following general recommendations for future library studies:

1. Determine the needs in terms of coordinated planning, cooperation, and hardware and software transferability which should be confronted before the fact, rather than after, as more and more regional operations take shape. 
2. Determine how libraries can develop the problem-solving and idea-producing capabilities of their staffs to the maximum.

3. Develop a continuing education program for librarians covering ISAD related topics that can be presented throughout the U.S. at a reasonable price per person per class.

\section{SUMMARY}

The first phase of library automation required a significant effort to develop information on the basic chores of running a library. As the studies moved from the testing ground to full operation they have started to generate a significant amount of information that can and should be exploited in turn to determine how library operations can be improved. Such "research" will generally tend to be "applied" rather than "pure." They will tend to concentrate on costeffectiveness at least as much as on novelty. The studies themselves need not beand almost undoubtedly should not be-multimillion dollar efforts. Although hardware and software developments will no doubt occur, the concentration appears to be more on planning and evaluating existing and proposed methods rather than on system "breakthroughs."

Respectfully submitted, Don L. Bosseau Michael D. Cooper Douglas Ferguson James L. Dolby, Chairman

\section{COMMITTEE ON RESEARCH TOPICS: MEMBERS REPORTS}

... Concerning ISAD related research and development needs, my first instinct was to try to think of needs occurring in hardware and software areas, but the influence of my new administrative duties has caused me to forego my old interest in systems work, by suggesting projects that are more planning oriented than technical.

(1) Determine the needs in terms of coordinated planning, cooperation, and hardware and software transferability which should be confronted before the fact, rather than after, as more and more regional OCLC type operations take shape. With centers now on the drawing boards for Texas, one in the Southeast at Atlanta or possibly Tulane University, the California State University and Colleges project, the University of California BibCenter, etc., it is possible that many of the duplications of effort of the past (involving individual libraries) could take place again, only on a larger scale. Of course, this gets into "networks," but there is a similarity with the problems posed in the past which were due to incompatibilities between individual library automation efforts, and the potential for the same problems occurring with the OCLC type of operations. Again, standard formats and other recent accomplishments will help alleviate the magnitude of the problems.

(2) With the implementation of a growing number of automated circulation systems, inventory control and processing systems, and the combined effects of tightening funding and inflated costs of library materials, libraries will, for the first time, have both a compelling reason to tighten up their collection development mechanism while also having available some of the statistical data required to determine the scope of material being collected. Thus a library could scien- 
tifically direct the nature of its acquisitions. Specifically (though perhaps not clearly) I am suggesting that there is a need for research to study and perhaps develop criteria which academic libraries of varying sizes can use to identify not just the subject matter of materials to be purchased, but actually place priorities on serial titles, perhaps some monographs, government documents, etc. which should reside in a given library. Such a set of criteria can be developed using circulation use statistics, statistical analysis of citation indexes, knowledge of the number of volumes and value of materials being published by subject areas and perhaps other factors. Using statistics derived from citation indexes, as an example, we evaluated our journal collection in several subject areas in an effort to determine whether we were deriving maximum benefit in terms of cost and coverage from our existing journal collection. To do so we utilized a recent article by Eugene Garfield ("Citation Analysis as a Tool in Journal Evaluation," Science, 178:471-79, 3 November 1972) which ranked journals by frequency and impact of citations. It was interesting to note that in some areas we were providing effective coverage of the literature for our faculty and research programs, whereas in other areas our collection was picking up only 1 percent to 2 percent of the useful information as evaluated on the basis of frequency of citation.

Of course what I am proposing is to do research into how this type of information can be stored and extracted, and evaluated to provide general academic libraries with scientifically based guides upon which to base their acquisitions programs.

(3) Where should libraries go with automation after inventory control, internal housekeeping functions, and MIS activities become routine? In other words, if there is going to be a Phase III (?) in library automation, where will its emphasis be, or better yet, where should it be?

I hope that this will provide at least something to think about and perhaps lead to a more clearly defined set of research topics.-DLB.

... A number of research topics seem to me worth exploring. However I have no idea whether they fall within the scope of ISAD.

(1) Economics of depository storage facilities. Should twelve million volume libraries be built, or should we have secondary storage facilities?

(2) Methodologies for dividing collection responsibility among members of a library consortium.

(3) How to predict the usage of individual monographs, not classes of material.

(4) Develop a continuing education program for librarians covering ISAD related topics. Present throughout the United States and at a price less than $\$ 10$ per person per class.

(5) Undertake a study to determine a new editorial policy for the Journal of Library Automation. My personal view would be that JOLA should move away from system descriptions and toward research topics.-MDC.

Libraries require research that will develop the capacity to improve existing operations and respond innovatively with new services, programs, and products. This requires applied research that produces immediately usable tools that can 
be applied by a library staff with a minimum of outside or specialist help. The focus is on the library staff at all levels (managers, supervisors, librarians, support personnel) and the aim is to enhance their ability to identify problems and formulate solutions within realistic constraints. The only way to move from the generality of these considerations to the concreteness of what I consider important is to state the questions to which applied research should address itself.

(1) How can libraries do more to supply needed information as well as documents and bibliographic references?

(2) How can libraries, with a minimum expenditure of time and money, determine how well they are serving their intended audience(s)?

(3a) How can libraries develop the problem-solving and idea-producing capabilities of their staffs to the maximum?

(3b) How can a library staff develop a cost-consciousness combined with an aggressive approach for funds for projects with demonstrable results?

\section{COMMENTS}

It should be clear that these questions assume that libraries can better serve their patrons if existing staff skills are developed at the same time as the library becomes more actively involved with those it serves. Technological development and multimillion dollar research are not needed. Managerial and staff cookbooks, library-based demonstration projects and on-the-job training programs are needed. Such tools and activities would help develop the flexible, mobile, and aggressive counterpart to the library's equally important passive, conserving, and stabilizing role.

\section{FOR EXAMPLE}

The proposed research might have the following kinds of results. It might show how library managers (directors etc.) use noneconomic rewards in the library work system to foster cost control and reduction, and new service ideas and opportunities to get in touch with library users. Research might produce a howto-do-it manual on user studies that might show how to use existing data or quickly gather data, perhaps on a sampling basis, to evaluate performance of a service or operational unit.-DF. 


\section{Report of the Committee on Seminar and Institute Topics}

\section{THE COMMITTEE}

The mission of the ad hoc committee as defined by the committee with the concurrence of Ralph Shoffner, president of ISAD, was: "To propose a plan for a program of seminars and institutes within the interests and educational needs of the Information Science and Automation Division (ISAD) of the American Library Association. The plan should cover the period commencing July 1974 and ending June 1978."

The members of the committee are: Pauline Atherton (Syracuse University), Brett Butler (Information Design, Inc.), Jay Cunningham (University of California-Berkeley), Paul Fasana (New York Public Library), Diana Ironside (Ontario Institute for Studies in Education), Sue Martin (Harvard University), Ron Miller (New England Library Information Network), Elaine Svenonius (University of Denver).

\section{THE APPROACH}

The committee began its work by placing the fulfillment of its mission firmly within the constraints of one major working assumption: that the educational function which the plan should serve must be directed toward accomplishing the objectives and needs of the ISAD membership.

Three parallel activities were undertaken as a result of our adherence to that assumption. First, a review of the extant data which resulted from seminars and institutes held by ISAD over the past several years was undertaken in order to identify characteristics of success or inadequacy which could be helpful to the committee. Second, the deliberations of a parallel group, the ISAD Committee on Objectives, were obtained to provide the context within which the plan will function. Third, the chairman of the ISAD Membership Survey Committee was interviewed for the purpose of including questions pertinent to seminar and institute topics in the proposed survey.

The remaining resources, external to the committee, were combined with the considerable experience and insight of the committee members. This experience includes continuing education techniques, information science research and education, automation of libraries and information services, computer and graphic technology, library cooperation and institute planning. Some members play important roles in ISAD conference planning. It was hoped that the combination of these resources could then be directed toward the intriguing prospect of developing some reasonable prescience about how technology may be applied to libraries and information science activities during the period ending June 1978.

The result of the first activity-a review of the historical data about ISAD seminars and institutes-is discussed below, followed by a series of recommendations formulated by the committee within the context of the objectives proposed and accepted by the ISAD Board of Directors. 


\section{SEMINAR AND INSTITUTE ACTIVITIES: HISTORICAL}

Table 1 summarizes some of the data available to the committee about thirtytwo seminar and institute programs held since 1968:

Table 1. ISAD Institutes 1967-1972.

\begin{tabular}{|c|c|c|c|}
\hline Dates & Programs & Location & Attendance \\
\hline $\begin{array}{c}1967 \\
\text { June } \\
1968\end{array}$ & State of the Art of Library Automation & San Francisco & 800 \\
\hline June & Automated Circulation Systems & Kansas City & 600 \\
\hline July & MARC Institute & Seattle & 94 \\
\hline Aug. & MARC Institute & Denver & 99 \\
\hline Sep. & MARC Institute & New York & 112 \\
\hline Oct. & MARC Institute & Chicago & 128 \\
\hline Nov. & MARC Institute & Boston & 126 \\
\hline $\begin{array}{l}\text { Dec. } \\
1969\end{array}$ & MARC Institute & Atlanta & 123 \\
\hline Feb. & MARC Institute & Cleveland & 120 \\
\hline Mar. & MARC Institute & Los Angeles & 120 \\
\hline Mar. & MARC Institute & Honolulu & 52 \\
\hline Apr. & MARC Institute & Houston & $(100+) ?$ \\
\hline Sep. & MARC Institute & San Francisco & 208 \\
\hline 1970 & & & \\
\hline Jan. & Tutorial on Library Automation & Washington, D.C. & 106 \\
\hline Mar. & MARC Institute & Washington, D.C. & 167 \\
\hline Mar. & Tutorial on Library Automation & Seattle & 79 \\
\hline Apr. & MARC Institute & Evanston, IL & 92 \\
\hline Apr. & Tutorial on Library Automation & Cambridge, MA & 107 \\
\hline May & Tutorial on Library Automation & New York & 156 \\
\hline June & MARC Institute & Cambridge, MA & 105 \\
\hline Oct. & Tutorial on Library Automation & Philadelphia & 123 \\
\hline Nov. & Tutorial on Library Automation & San Francisco & 72 \\
\hline $\begin{array}{l}\text { Dec. } \\
1971\end{array}$ & Library Automation for School Libraries & Dallas & 38 \\
\hline Feb. & Library Automation for School Libraries & Atlanta & 80 \\
\hline Mar. & Tutorial on Library Automation & Elgin, IL & 77 \\
\hline Apr. & MARC Institute & New York & 100 \\
\hline May & Administration \& Management & Dedham, MA & 54 \\
\hline $\begin{array}{l}\text { Nov. } \\
1972\end{array}$ & Directions in Information Science Education & Denver & 67 \\
\hline Feb. & MARC Institute & Washington, D.C. & 139 \\
\hline May & Microforms in Library Automation & New York & 53 \\
\hline June & Administration \& Management & New York & 52 \\
\hline Sep. & Seminar on Telecommunications & Washington, D.C. & 110 \\
\hline
\end{tabular}

Estimated Attendance: 4,460

By the end of September 1972, thirty-two seminars or institutes had been held across the United States from Boston to Honolulu. Fifty percent of the sessions were concerned directly with the exposition and use of either the MARC I or MARC II communications formats. The remaining seminars dealt with topics such as the introduction to library automation in general and to school libraries in particular, as well as library automation management, information science education, micrographic and telecommunications technologies.

As a group, the MARC-related institutes reached approximately 1,900 people 
(not allowing for multiple attendance); or 43 percent of the total attendance over the five-year period. The most heavily attended institutes were those held either immediately before or after annual conferences of ALA or ASIS. The Northeast Region (Boston area, New York, Philadelphia, and Washington, D.C.) hosted fourteen institutes; the Midwest Region (Chicago area, Cleveland, and Kansas City) hosted five; the Southwest (Denver, Houston, and Dallas) hosted four; the West Coast (Los Angeles and San Francisco) also hosted four; the Northwest (Seattle) and Southeast (Atlanta) regions each were the site of two institutes. One institute was held in Honolulu, and another was canceled.

If pre- and post-conference institutes are excluded, the arithmetic mean attendance at a typical institute was approximately 98 . The range was from a low of 38 (Library Automation for School Libraries in Dallas, December 1970) to a high of 167 (MARC Institute in Washington, D.C., in March of 1970). It is risky to conjecture why any single institute was more successful than another purely on the basis of attendance. Attendance figures are probably more nearly a function of the expectations of the target population, the magnetism of the topic and how much physical and financial investment is required to attend. There is little doubt, however, that the best attendance can be obtained if seminars are held immediately before or after an annual meeting of ALA or ISAD in the same city.

Some post-institute evaluative data, also provided by ISAD headquarters, seemed to indicate that when dissatisfaction with institutes was registered by participants, it was derived from the diverse backgrounds of participants who attended institutes. For some, the content was too elementary; for others, it was too advanced. Some attendees were technologists while others were managers. Both large and small libraries of all types were represented. Another factor relating to the apparent effectiveness of a particular institute was the perceived competence or teaching ability of particular institute faculty members. These factors do not reveal themselves as startling revelations, but do imply that some care should be used to describe and reach particular target populations, and to select instructional leaders.

Another important fact: between two-thirds and three-quarters of the participants of a typical institute were not members of ISAD. It is readily apparent therefore, that these programs have reached an audience drawn from a broad segment of the library professional community. This condition is no doubt a good one, but it may imply a differential registration fee structure as well as a fruitful context in which to recruit new division members.

With these considerations of the past in mind, the committee offers the comments and recommendations which follow. It should not be assumed that these recommendations are necessarily endorsed unanimously by the committee members.

\section{SEMINAR AND INSTITUTE ACTIVITIES: RECOMMENDATIONS}

1. The ISAD Committee on Seminar and Institute Topics and the ISAD Committee on Objectives fully concur that the Seminar/Institute program has been valuable as a division activity in service of the profession.

The Committee therefore recommends that a program of seminars and institutes be continued and broadened by the division during the next five years. 
2. A history of fruitful conjoining of the division's seminars and institutes program with the Library of Congress, the American Society for Information Science and other institutes and associations has been mutually beneficial.

The Committee therefore recommends that a conscious effort be made to continue the division's seminars and institutes program in cooperation with appropriate activities within the Library of Congress and other federal library-oriented activities (such as the Federal Library Cooperative Center), and expand its target population and faculties to include members of ASIS, ACM, IIA, AFIPS and JCET.

3. The geographic distribution of previous seminars and institutes based upon population concentrations has appeared to be reasonably sound.

The Committee therefore recommends that the division's seminars and institutes program continue to disperse and replicate seminars among six geographic regions; the Northeast, Southeast, Midwest, Southwest, West and Northwest. The Gulf Coast area should be considered as a central location for programs which the division may co-sponsor with the Southeastern Library Association and the Southwestern Library Association. Programs occurring in the northern half of the continental United States should coordinate with our Canadian counterparts.

4. Technological advances which may be applicable to the concerns of the division are developing with astonishing speed.

The Committee therefore recommends that an "Alert Group" be formed from technically aware people for the purpose of formulating topics which should be considered by the planning group assigned to monitor the division's seminars and institutes program. A secondary source for topical input to a planning group should be the inclusion of "a topic alert form" included in the division's publications.

5. Planning and implementing a series of seminars and institutes is a severe time burden on volunteers.

The Committee therefore recommends that the reliance upon voluntary workers to design and implement seminars and institutes should diminish, the major burden of such work passing to staff responsible for this work at ALA headquarters. The staff salary should be substantially reimbursed from income derived from the program. Further, subcontractors whose products are educational programs, as opposed to systems, hardware or supplies, should be considered as supplemental manpower to both voluntary committee work and ISAD staff investment in particular seminars or institutes.

6. Commercial interests may have particular products to sell to the ISAD community and view the division's seminars and institutes program as a channel through which their products can be marketed.

The Committee therefore recommends that a policy be formally adopted which permits the participation of representatives of commercial enterprises in the seminars and institutes program under the condition that appropriate competitors have equal and simultaneous opportunity to offer alternative products or points of view. The division must maintain its professional distance from any one technological solution to a particular set of problems. 
7. Dissatisfaction on the part of some institute participants has been attributed to (1) participant heterogeneity, (2) misplaced expectations, (3) inadequacies in seminar faculties.

The Committee therefore recommends that the target populations be clearly defined and subgroups be given special attention; that expectations be clearly spelled out in publicity announcements and that faculty members be selected with care.

8. The most useful measure of success in any educational program is purported to be evidenced by some behavioral or attitudinal change on the part of the "educatee" occurring after a defined educational experience.

The Committee therefore recommends that, where possible, evaluation techniques be used on a sampling basis to obtain such evidence after a period of time has elapsed beyond the occurrence of the seminar experience.

9. A limited number of people have been able to attend particular seminars because of the barriers of time, cost, and space.

The Committee therefore recommends that a supplemental program using edited audio or video media be attempted to promulgate institute segments in shortened time frames.

10. Several colleges and universities are committed to continuing education in information science and library automation.

The Committee therefore recommends that, when appropriate, the talent of selected graduate schools be considered as resources for faculty and for program planning. One prerequisite to maximize the success of this type of alliance is evidence that the objectives of the ISAD seminars and institutes program are coincident with the objectives of the continuing education programs of such graduate schools.

11. Information science has not received much attention per se within the seminars and institutes program, and the committee regards this state of affairs as insufficient to attain the objectives of the division.

The Committee therefore recommends that a working definition of information science be promulgated by the division to provide guidance for planning seminars and institutes for its practitioners. In this connection, close liaison with ASIS and special interest groups in other organizations is a natural procedure to follow.

12. The technologies which appear to have a growing impact upon library and information center operations and services are: computers, micrographics, media systems, and telecommunications.

The Committee therefore recommends that the division's seminars and institutes program planners seek to provide a series of tutorials not only on the operations and applications of these technologies taken separately, but also on the inter-relationships which are possible among them.

13. Based upon suggestions contributed by the Committee members and others, the following topical areas are recommended for consideration in planning for future seminars and institutes.

A. Interlibrary Cooperation

1. Technological options 
2. How to choose a network

3. Variant forms of MARC (e.g., serials, music, etc.)

B. Technology

1. The interrelationships of computers, micrographics, instructional media systems and telecommunications

2. Mini-computers

3. Telecommunications

4. Non-print audio and visual technology

5. Techniques of data base storage, search and retrieval: trade-offs

6. The emergence of commercial jobbers in support of library automation

C. Internetwork compatibility

1. Network transferability

2. Data base interchange

3. Methods of interconnection through telecommunications

4. Standards and protocols

D. Management and People

1. Impact of automation on people and jobs

2. Automation, networks and educational needs of librarians

3. Contract negotiation

4. Problem solving for library managers

5. The impact of nonlibrarians on library automation and information science

6. The theory and application of interinstitutional cooperation: quid pro quo revisited

7. Why automation projects fail.

Respectfully submitted, Pauline Atherton Brett Butler Jay Cunningham Paul Fasana Diana Ironside Sue Martin Elaine Svenonius Ronald Miller, Chairman 